UDC 546.15: 574: 577.1

\title{
IODINE IN ABIOTIC AND BIOTIC ENVIRONMENTS
}

\author{
H. L. Antonyak', N. E. Panas², O. I. Pershyn ${ }^{3}$, A. I. Polishchuk', N. K. Hoyvanovych ${ }^{4}$ \\ ${ }^{1}$ Ivan Franko National University of Lviv, 1, Saksaganskyi St., Lviv 79005, Ukraine \\ e-mail: halyna_antonyak@yahoo.com \\ 2 Lviv National Agrarian University \\ 1, Volodymyr Velykyi St., Dubliany, Lviv region 80381, Ukraine \\ ${ }^{3}$ Danylo Halytsky Lviv National Medical University, 69, Pekarska St., Lviv 9010, Ukraine \\ ${ }^{4}$ Ivan Franko Drohobych State Pedagogical University \\ 23, T. Shevchenko St., Drohobych, Lviv region 82100, Ukraine
}

Antonyak H.L., Panas N.E., Pershyn O.I., Polishchuk A.I., Hoyvanovych N.K. Iodine in abiotic and biotic environments. Studia Biologica, 2018: 12(2); 117-134 • https://doi.org/10.30970/sbi.1202.567

lodine, a trace element belonging to halogens, is a natural component of the Earth's environment. However, its distribution in the environmental compartments is uneven and highly variable. lodine is scarce in soil-forming parent rocks, soils and continental waters, but it is more abundant in the marine environment and organic rich sedimentary rocks. lodine is ubiquitous in the biosphere, being found in virtually all organisms, both eukaryotes and prokaryotes. In vertebrates, including humans, iodine is used primarily for synthesis of thyroid hormones involved in the regulation of cellular metabolism and a host of vital body functions. Inadequate iodine intake by humans leads to serious health problems due to thyroid dysfunction and insufficient formation of thyroid hormones (endemic goitre, neurological abnormalities, cognitive impairment, physical development disorders, etc.). Many other biota groups living in different habitats can efficiently concentrate this element by absorbing inorganic iodine species from abiotic environments with the formation of various iodine-containing organic substances. Some of these compounds can serve metabolic and signaling functions in producing organisms, while others, such as volatile halocarbons, are involved in the transfer of iodine from the marine and terrestrial environments to the atmosphere. Consequently, terrestrial, soil and aquatic organisms (including microbial populations) capable of accumulating, metabolizing and volatilizing iodine mediate the processes of its biotransformation in the environment and contribute to the global iodine cycle. Marine organisms (algae, invertebrates) are stronger bioconcentrators of iodine in comparison with terrestrial biota. Brown algae of the genus Laminaria are the most potent iodine accumulators among all living systems. This

(C) 2018 H. L. Antonyak et al.; Published by the Ivan Franko National University of Lviv on behalf of Біологічні Студії / Studia Biologica. This is an Open Access article distributed under the terms of the Creative Commons Attribution License (http://www.budapestopenaccessinitiative.org/ and Creative Commons Attribution 4.0 License), which permits unrestricted reuse, distribution, and reproduction in any medium, provided the original work is properly cited.

ISSN 1996-4536 (print) • ISSN 2311-0783 (on-line) • Біологічні Студії / Studia Biologica • 2018 • Том 12/№2 • С. 117-134 
article describes the distribution of iodine in abiotic and biotic environments, and the involvement of biotic processes in the biogeochemical cycle of iodine.

Keywords: iodine, environment, ecosystems, biota, marine algae, thyroid hormones

\section{INTRODUCTION}

lodine (I), a member of the halogen group of elements with atomic number 53 and atomic mass of 126.9 , was discovered in 1811 by Bernard Courtois in seaweed ash du ring the manufacturing of potassium nitrate. It was independently identified as a chemical element in 1813 by Louis-Joseph Gay-Lussac and Humphry Davy [40]. lodine is almost the least reactive among halogens (with the exception of astatine); however, it has a relatively high chemical reactivity compared with other non-metals and exhibits multiple oxidation states (from -1 to +7 ).

lodine is a trace element of the earth's crust with an average concentration of about $0.5 \mathrm{mg} / \mathrm{kg}$, characterized by an uneven and highly variable distribution in different compartments of the environment. The element is scarce in soil-forming parent rocks, but is more abundant in marine environment and organic-rich sediments, as well as in brackish waters and subterranean brines associated with natural gas and oil fields [32, 38, 42]. lodine naturally occurs as a minor constituent in the composition of various minerals, but most of them are rare and not concentrated in deposits. Exceptions include lautarite and dietzeite, calcium iodate-containing minerals found at higher concentrations in nitrate deposits (caliche ore) located in the Atacama Desert in Northern Chile, the world's leading province for iodine production [42].

lodine belongs to elements circulating in the environment along a cyclic path known as the biogeochemical cycle, which involves the geosphere, hydrosphere, atmosphere and the biosphere. It is accepted that only a small part of iodine in terrestrial environments originates from the rock weathering, while most of the element in soils and freshwater systems is derived from the world oceans, the main mobile pool of iodine in its global cycle [32]. The enrichment of soils and terrestrial vegetation with iodine occurs mainly via its volatilisation from ocean surface to the atmosphere and subsequent transfer to the land by dry and wet deposition. Soils are also involved in the global iodine cycle, being the second largest source of iodine volatilization to the atmosphere after the oceans [32, 42]. At the same time, the transformation of inorganic iodine species into organically bound iodine and vice versa with the participation of predominantly biological processes contributes to the natural circulation of iodine between abiotic and biotic environments $[4,25,46,50]$.

lodine is ubiquitous in the biosphere and it is required for life processes by many groups of organisms that inhabit Earth. This is especially relevant for vertebrate organisms endowed with specialized mechanisms of iodide concentration in the thyroid gland and the synthesis of iodine-containing hormones, potent regulators of cellular metabolism and vital body functions [26, 27, 35]. Apart from being an essential micronutrient for vertebrates, iodine is absorbed from the environment and metabolized by other biota groups living in aquatic, terrestrial and soil ecosystems. lodine-accumulating species capable of efficiently concentrating iodine from abiotic media are found among animal taxa devoid of follicular thyroid tissue such as invertebrates and primitive vertebrates, as well as among members of other eukaryotic groups and prokaryotes [4, 25, 30, 48].

ISSN 1996-4536 (print) • ISSN 2311-0783 (on-line) • Біологічні Студії / Studia Biologica • 2018 • Том 12/№2 • С. 117-134 
Marine algae, especially those belonging to the class Phaeophyceae, are widely known for their high iodine-accumulating capacity; moreover, the brown algae of the genus Laminaria possess the highest ability to concentrate iodine among all living systems [47].

Different groups of biota that inhabit natural ecosystems can convert absorbed inorganic iodine into an organic form by means of enzymatic iodination processes. To date, more than 100 organic iodine-containing compounds of biotic origin, including volatile halocarbons, have been identified $[29,48]$. Emissions of biogenic methyl iodide $\left(\mathrm{CH}_{3} \mathrm{I}\right.$, the most common member of natural iodocarbons) from different types of ecosystems have been widely studied with respect to global atmospheric chemistry [18, 50, 71, 88].

The purpose of this article was to provide an overview of the distribution of iodine in biotic and abiotic environments with an emphasis on the role of terrestrial, soil and aquatic biota in the global iodine cycle.

\section{Chemical speciation of iodine in the environment}

lodine exists in the natural environment in several oxidation states and in the form of various inorganic and organic species with different reactivity and mobility in abiotic environments [32, 46]. Chemical speciation of iodine occurs in different environmental compartments (e.g. natural waters, soil and atmosphere), being very sensitive to ecological factors, including physical, chemical and biological parameters of local media. In soil and aquatic environments, a range of iodine species can coexist in different proportions depending on $\mathrm{pH}$, redox potential (Eh), content of organic matter, sunlight intensity, temperature, and microbial activity $[4,59,75,90]$. In the atmosphere, iodine speciation involves a variety of photochemical reactions occurring between iodine gaseous species (both inorganic and organic) and oxidants in the presence of sunlight [88].

The predominant species of iodine in the environment are $\mathrm{I}^{-}$(iodide), $\mathrm{IO}_{3}^{-}$(iodate), and organic iodine [46]. Small portions of $\mathrm{I}_{2}$ (molecular iodine) and $\mathrm{HIO}$ (hypoiodous acid) may also exist in the atmosphere, hydrosphere and soils, but their lifetimes are very short. The prevalence of iodide or iodate in soils and natural waters is highly dependent on $\mathrm{pH}$ and the redox status of the surrounding milieu [75]. Under oxidizing conditions, iodine is mainly present in the form of a more reactive iodate anion, whereas the iodide anion predominates under reducing conditions, such as those observed in the paddy soil.

lodide is the most common inorganic form of iodine in freshwaters, while iodate is more prevalent in marine and oceanic waters [1, 91]. However, reduction of iodate via biological, chemical and photochemical processes leads to the formation of iodide in the surface layers of seawater and in coastal waters with considerable variations in the concentration of each species: $\mathrm{I}^{-}$in the range of $<1-25 \mathrm{mg} / \mathrm{L}$, and $\mathrm{IO}_{3}{ }^{-}$in the range of 25-60 mg/L [24]. Maximum concentrations of iodate are recorded in deep oligotrophic waters, where the reduction reactions are less common. lodate also prevails in the oxidizing alkaline conditions of hot desert soils, reaching the highest levels (an average of $344 \mathrm{mg} / \mathrm{kg}$ ) in the Atacama Desert, the driest desert on Earth [3]. lodide and iodate anions exhibit the disparate sorption behaviour and different mobility in soils: less reactive iodide is considered more mobile, while iodate is effectively adsorbed to soil components such as ferric and aluminium oxides and organic matter [43]. In soil pore water, iodine is present mainly as $\mathrm{I}^{-}$anion.

Organically bound form of iodine, apart from inorganic iodine species, constitutes a significant part of iodine in natural environments. Living organisms are able to synthe-

ISSN 1996-4536 (print) • ISSN 2311-0783 (on-line) • Біологічні Студії / Studia Biologica • 2018 • Том 12/№2 • C. 117-134 
size a broad spectrum of structurally diverse biomolecules containing one or more carbon-iodine bonds, including mono- and diiodotyrosines, iodothyronines, alkyl iodides and others [29, 48, 79]. In addition, iodination of organic matter components (e.g. proteins, lipids, polyphenols, humic substances) with the aid of both abiotic and biotic processes can occur in soils, sediments and natural waters [41, 46]. Transformation of inorganic iodine species to organic iodine plays an important role in iodine immobilization, especially in a surface soil-water system. lodinated organic substances obtained from decomposing biogenic material, as well as from the process of iodination of sedimentary organic matter, can persist for a long time in marine sediments and subterranean waters. For instance, halogenated fulvic acids have been found in groundwater samples that date back 1,300, 4,600 and 5,200 years. An analysis of 35,000-year-old organic matter has also shown the presence of organoiodine compounds in it [86].

Organically bound iodine was observed as the major iodine fraction in natural freshwaters, including river water and groundwater, and in peat bogs that usually contain high concentrations of dissolved organic carbon [33]. In surface layers of seawater, as well as in coastal waters and estuaries, organically bound iodine accounts for up to $40 \%$ of the total iodine content [1]. Organoiodine compounds also constitute a certain portion of iodine in atmospheric aerosols and precipitations [33].

Among natural organoidine compounds generated in various environments, volatile halocarbons are the main carrier of iodine from marine and terrestrial ecosystems to the atmosphere. In particular, the massive amounts of methyl iodide ( 1 to $4 \times 10^{11} \mathrm{~g}$ per year) are released into the atmosphere from the water surface layers in open oceans and marine coastal areas [4]. In addition to methyl iodide, a number of other halocarbons (such as $\mathrm{CH}_{2} \mathrm{I}_{2}, \mathrm{CH}_{2} \mathrm{ICl}$ and $\mathrm{C}_{3} \mathrm{H}_{7} \mathrm{l}$ ) have been detected in the atmosphere, as well as in oceanic water [88].

\section{2. lodine in the abiotic environment}

\section{1. lodine in the hydrosphere}

World oceans are the main repositories of natural iodine (about $70 \%$ of the Earth's surface inventory) and represent the dominating source of its supply to the terrestrial environment and the biosphere [36]. lodine input into the marine hydrosphere is due to a number of environmental processes on a global scale, such as leaching from the upper Earth's crust, eruption of submarine and terrestrial volcanoes, surface continental runoff and atmospheric deposition [2]. Volatilization of iodine from the oceans to the atmosphere in the form of gaseous molecular iodine and organic compounds such as alkyl iodides is a key part of the global iodine cycle. A significant portion of the iodine-containing volatiles released to the atmosphere from the oceans is produced by marine organisms (macroalgae, phytoplankton, microorganisms) [4, 48, 50, 85]. Abiotic processes in seawater also contribute significantly to the emission of iodine from the oceans.

Oceanic iodine is largely accumulated in bottom sediments, which contain most of the iodine present in the hydrosphere. The amount of iodine stored in this reserve is estimated at about $1.2 \times 10^{16} \mathrm{~kg}$ [61]. lodine concentration in marine sediments is of 3-400 mg/kg, in contrast to freshwater sediments with an iodine content of about $6 \mathrm{mg} / \mathrm{kg}$.

Concentration of iodine in seawater averages $45-60 \mu \mathrm{g} / \mathrm{L}[68,91]$ and tends to vary slightly depending on depth and salinity. Continental surface waters, including lakes, rivers and streams, generally have significantly lower iodine levels in comparison to the seawater, with standing waters typically containing higher iodine concentrations than

ISSN 1996-4536 (print) • ISSN 2311-0783 (on-line) • Біологічні Студії / Studia Biologica • 2018 • Том 12/№2 • С. 117-134 
running waters in the same area. Most freshwater systems contain iodine at concentrations of $<20 \mu \mathrm{g} / \mathrm{L}$, with many values being in the range of $0.5-5 \mu \mathrm{g} / \mathrm{L}[32,91]$, including several European rivers in which iodine levels vary from 0.90 to $4.20 \mu \mathrm{g} / \mathrm{L}[58,72]$. Low iodine concentrations have been found in the rivers of Alaska and Canada (0.60$2.90 \mu \mathrm{g} / \mathrm{L}$ ) [58], whereas the range of geometric mean iodine content in Japanese rivers was reported to be of $0.18-8.34 \mu \mathrm{g} / \mathrm{L}$ [82]. However, significantly elevated iodine levels in river waters have been recorded at several geographic locations, such as the U.S. South Coast (5.5-212 $\mu \mathrm{g} / \mathrm{L})$ [58] and the San Juan province in Argentina (16-95 $\mu \mathrm{g} / \mathrm{L})$ [89]. In general, the iodine content of freshwaters depends on many factors, including the location of river basins, the distance from the seacoast, geological characteristics of the territory, climatic and seasonal factors, precipitation levels, sorption-desorption processes in sediments, and anthropogenic activities in catchment areas [72].

In contrast to most freshwaters, some internal saline lakes (e.g. located in China and Western Mongolia) contain high iodine concentrations [38]. Significant amounts of iodine are contained in subsurface brines associated with natural gas and oil fields. In brines extracted industrially in Japan, iodine is found at concentrations of up to $160 \mathrm{mg} / \mathrm{L}$, while brines of the Pennsylvanian age Morrowan Formation in Oklahoma contain it in a concentration of 150 to $1200 \mathrm{mg} / \mathrm{L}$ [42].

\section{2. lodine in the lithosphere and soils}

lodine is typically present in low concentrations in the lithosphere (an average of about $0.3 \mathrm{mg} / \mathrm{kg}$ ), with the lowest levels occurring in igneous rocks such as basalts and granites (0.22 and $0.25 \mathrm{mg} / \mathrm{kg}$, respectively) [32]. By contrast, higher concentrations of iodine are found in sedimentary rocks, in which its content usually correlates with the amount of organic matter. Marine deposited rocks are much richer in iodine than nonmarine deposits, with the highest levels being reached in the recent sediments (5$200 \mathrm{mg} / \mathrm{kg}$ ). Average iodine contents of carbonates, shale and sandstones are of 2.7, 2.3 and $0.8 \mathrm{mg} / \mathrm{kg}$, respectively [32].

Soils generally contain higher amounts of iodine than parent rocks. The iodine content of soils with an average value of $3 \mathrm{mg} / \mathrm{kg}$ varies over a wide range $(0.5-50 \mathrm{mg} / \mathrm{kg})$, depending on soil type, parent material, location and climatic factors [59]. Most of the soil iodine is derived from the marine atmosphere, so coastal soils are enriched with this element, and those located in mountainous regions and central continental areas are relatively depleted of iodine [32]. A number of natural factors contribute to the depletion of soil iodine, including iodine volatilisation and washing out by surface waters and groundwater, seasonal flooding, heavy rainfalls, soil erosion and weathering. Soils can volatilise molecules of elemental iodine and volatile organic compounds formed in both abiotic and biological processes. Subsequently, part of the iodine is transported to the land via rainfall and dry deposition. This process plays an important role in the transfer of iodine to terrestrial biota with special significance in areas remote from the seas and oceans.

The iodine content in soils strongly depends on soil ability to retain iodine against its loss due to volatilization and leaching processes. Retention of iodine in soils is closely related to its adsorption-desorption behaviour depending both on the iodine speciation and on soil characteristics. There are many factors that affect the iodine adsorption in soils, such as $\mathrm{pH}$, redox potential (Eh), amount of organic matter, iron and aluminium oxides and hydroxides, calcium carbonate, soil texture and temperature [59, 75, 91]. Organic matter plays a principal role in retaining iodine; as a result, the highest levels of

ISSN 1996-4536 (print) • ISSN 2311-0783 (on-line) • Біологічні Студії / Studia Biologica • 2018 • Том 12/№2 • C. 117-134 
this element are found in the upper soil layers [90]. A high level of clay minerals and iron and aluminium hydroxides in soils is also an important factor contributing to iodine retention. Sandy soils and soils with low clay contents are reported to have very low levels of iodine, while clay-rich soils, organic rich soils and alkaline soils are richer in this element. However, adsorption onto soil components strongly affects the mobility of iodine and, consequently, reduces its bioavailability in some soils enriched with organic matter and clays. In particular, peats and peat soils that often contain more iodine than other types of soils due to a large amount of organic matter [32] are not good providers of this element to the food chain because of its low mobility and bioavailability to plants. It has been shown that, due to strong binding of iodine in soils, only $0.1 \%$ of the total soil iodine is transferred to plant biomass [13].

Owing to the geological history of soil formation, as well as geographical and climatic reasons, soils in many regions of the world are poor in iodine. lodine-depleted soils were found mainly in mountainous areas such as the Himalayas, the European Alps, the Pyrenees and the Andes. Most of the iodine was removed from these soils during the past glaciations, weathering and erosion. Soils of low iodine status are also common in flooded river valleys, such as the Ganges in India, in lowland areas remote from the oceans, such as Central Africa and Eastern Europe. In North America, iodinedeficient soils occur in the Great Lakes, Appalachians, the North-Western part of the United States and parts of Canada [62]. Additionally, many anthropogenic activities related to land use, including intensive agriculture, the use of alkaline fertilizers, overgrazing, and deforestation, tend to deplete iodine in soils, which in turn can affect soil ecosystems and human health.

\section{3. lodine in the atmosphere}

lodine is an important trace element in the atmosphere, which serves the crucial role in iodine circulation between the hydrosphere, the land surface and the biosphere. Volatilization of iodine from the oceans to the atmosphere in the form of gaseous molecular iodine and organic compounds such as alkyl iodides is a key part of the global iodine cycle [32]. Other inputs of iodine to the atmosphere occur from the land surface mainly by natural processes, such as volatilisation from soils and terrestrial vegetation, and partly from anthropogenic activities, including the combustion of fossil fuels. However, anthropogenic inputs are considered insignificant on a global scale compared with natural iodine emissions from the marine hydrosphere.

The global average iodine level in the atmosphere is in the range of $10-20 \mathrm{ng} / \mathrm{m}^{3}$ [91], with concentration typically ranging from 2 to $14 \mathrm{ng} / \mathrm{m}^{3}$ in air over land and from 17 to $52 \mathrm{ng} / \mathrm{m}^{3}$ in air over the oceans [68]. Atmospheric iodine includes gaseous inorganic, gaseous organic and particulate forms, which have different average atmospheric residence time (10, 18 and 14 days, respectively) [22]. From the atmosphere, iodine is deposited on land, continental water bodies, and also on ocean surface by means of rain, snow, wind and oceanic spray. lodine concentration in rainwater was shown to be in the range of $1-15 \mu \mathrm{g} / \mathrm{L}$ over oceans and of $0.1-15 \mu \mathrm{g} / \mathrm{L}$ over land [68]. Estimated deposition of iodine onto the soil with rain and snow amounts about $16 \mathrm{~g} / \mathrm{ha}$ per year, while the amount of dry deposition is about $9.6 \mathrm{~g} /$ ha per year [91].

lodine plays an important role in atmospheric photochemical processes [18, 71 , 88]. After being volatilized from marine and terrestrial environments, both organoiodine compounds and $\mathrm{I}_{2}$ molecules undergo photochemical transformations, including their

ISSN 1996-4536 (print) • ISSN 2311-0783 (on-line) • Біологічні Студії / Studia Biologica • 2018 • Том 12/№2 • С. 117-134 
dissociation and generation of iodine radicals ( $\left(^{*}\right.$ and $\left.I^{*}\right)$, which can interact with atmospheric species such as $\mathrm{O}_{3}, \mathrm{H}_{\mathrm{x}} \mathrm{O}_{y}$, and $\mathrm{NO}_{x}$. This results in the destruction of ozone molecules, changes in the $\mathrm{HO}_{2} / \mathrm{OH}$ and $\mathrm{NO}_{2} / \mathrm{NO}$ ratios, and the formation of hydroscopic higher-order iodine oxides $\left(\mathrm{I}_{\mathrm{x}} \mathrm{O}_{\mathrm{y}}\right)$ giving rise to aerosol particles, precursors of cloud condensation nuclei $[45,71]$. Thus, the speciation and dynamics of atmospheric iodine is of particular interest in the aspect of its potential impact on global climate processes.

\section{3. lodine in the biotic environment}

\section{1. lodine in organisms inhabiting natural ecosystems}

lodine is found in organisms belonging to all three domains of life (Eukarya, Bacteria and Archaea), and many biota groups, including microbial populations, are known to accumulate and metabolise this element, thereby participating in its environmental cycle.

Several strains of iodine accumulating bacteria have been isolated from marine sediments, seawater and brine waters, as well as from subsurface aquifer sediments [4, $5,52]$. In particular, the bacterial strain, which concentrate iodide by a factor of $6 \times 10^{3}$, has been isolated from marine sediments [5]. Bacterial strains capable of oxidizing iodide, as well as iodate-reducing microbial strains were isolated from environmental samples [4]. lodide oxidizing enzymes, including laccase and peroxidases released by microorganisms, can promote the formation of organically bound iodine in natural environment [73]. A range of soil microorganisms (bacteria, ectomycorrhizal and wood-rotting fungi) can transform iodide into $\mathrm{I}_{2}$ and organic iodine species, including volatile methyl iodide [4, 67]. Thus, microorganisms participate in iodine cycling in the environment through processes such as volatilization, accumulation, reduction, oxidation and sorption. In addition, microorganisms are involved in degradation or dehalogenation of iodinated aliphatic and aromatic compounds, and several aerobic bacteria capable of growing on methyl halides (including $\mathrm{CH}_{3} \mathrm{I}$ ) as a sole source of carbon and energy have been isolated [4].

lodine is not considered to be an essential mineral for terrestrial plants, and its content in terrestrial vegetation is generally low, with concentrations ranging from 0.07 to $10 \mathrm{mg} / \mathrm{kg}$ in typical land plants and food crops [69]. However, iodine content of some crops and vegetables can be significantly increased with increasing concentration of exogenous iodine under hydroponic conditions or using iodine-containing fertilizers [34]. lodine that is present in soil solution can be taken by plants in the form of iodide or iodate anions, albeit at different rates. Iodide is considered more bioavailable to plants because of its better solubility and higher mobility in the soils. In addition to absorbing iodine via roots, plants can accumulate this element from atmospheric air and precipitations through their leaves and other aboveground parts [34, 91]. Absorption of airborne iodine is especially important for bryophytes that do not possess a true root system, and plays a critical role in the uptake of iodine by lithophytic and epiphytic mosses that have no attachment to soils. Many studies have provided evidence that these primitive plants often contain as much iodine as do ordinary terrestrial plants. In particular, mosses sampled in pristine areas of South-Eastern Europe have iodine content in the range of $0.36-6.31 \mathrm{mg} / \mathrm{kg}$ [55].

Although there has been no direct evidence of iodine essentiality in terrestrial plants, there are many reports suggesting its positive effects on plant growth and some metabolic processes in plant cells, including the improvement of the antioxidant response in stressful conditions $[20,34,51,53]$. Studies using medicinal plants have revealed that the 
application of iodine-containing plant growth stimulants (e.g. Vermyiodis) provides for increased productivity, improves antioxidant status and the formation of some biologically active substances such as carotenoids and flavonoids in Calendula officinalis and Matricaria recutita $[53,54]$. However, an overdose of iodine is known to be harmful to terrestrial plants. Excessive accumulation of iodine in plant tissues may adversely affect plant growth or can lead to toxic effects [20,34]. The flooding of paddy soils has long been known to produce Akagare disease in rice as a result of the high level of iodide uptake.

It has been shown that land plants can volatilize some amounts of iodine in the form methyl iodide [32, 70]. Consequently, terrestrial vegetation participates in the global circulation of iodine between the land surface and the atmosphere.

Unlike terrestrial biota, marine organisms are potent iodine concentrators from seawater, in which most of the iodine is in bioavailable form. Some orders of brown algae (Phaeophyceae), such as Laminariales, are most widely known for their high capacity to accumulate iodine. These plants are able to concentrate it up to 30,000 times compared to seawater and maintain iodine concentration in the thallus of about $1 \%$ of dry weight and higher (up to $4.7 \%$ in juvenile plants) [47]. The highest content of iodine has been reported in the species of the genus Laminaria with the maximum levels in Laminaria digitata (up to $6.12-8.17 \mathrm{~g} / \mathrm{kg}$ of dry weight) and Laminaria ochroleuca (up to $6.14 \mathrm{~g} / \mathrm{kg}$ of dry weight) [21]. The Laminaria species are considered to be the strongest iodine bioaccumulators not only among aquatic plants, but also among all living organisms [46]. Both the green algae (Chlorophyta) and red algae (Rhodophyta) generally contain lower levels of iodine in their thalli compared with the brown algae.

It has been found that seawater iodine is taken by Laminaria species and other Laminariales in the form of iodide, which initially enters an extracellular matrix located in algal peripheral tissue. lodide can be oxidised into hypoiodous acid and molecular iodine with the aid of cell wall vanadium-dependent haloperoxidase (V-HPO), which uses photosynthetic hydrogen peroxide $\left(\mathrm{H}_{2} \mathrm{O}_{2}\right)$ on a routine basis and peroxide generated by oxidative burst under stress conditions [47]. Oxidised iodine can then cross the plasma membrane and enter cells, where it is reduced to iodide or diverted to iodinating organic substrates. However, under stressful conditions, an oxidative burst triggers a massive mobilization of iodide from the intracellular reservoir. This leads to V-HPOmediated formation of volatile halocarbons using $\mathrm{H}_{2} \mathrm{O}_{2}$ produced in large amounts in the apoplast. From this point of view, it has been suggested that the biological role of accumulated iodine in brown algae consists in its acting as an inorganic antioxidant that protects algae from oxidative damage in environmental stresses [45, 47].

Marine microalgae can absorb iodine in the form of iodate and iodide [39], participate in the iodate-to-iodide speciation and release iodine as methyl iodide into the environment [18]. Therefore, microalgae together with macroalgae and marine microorganisms mediating the volatilization of iodine into the atmosphere are believed to play an important role in the global iodine cycle [50].

lodine is abundant in marine animals, both in vertebrates and invertebrates, including sponges, corals, crustaceans and mollusks [29, 65]. The reported iodine concentrations in edible marine invertebrates range from $308 \mu \mathrm{g} / \mathrm{kg}$ in crab tissues to $1300-1400 \mu \mathrm{g} / \mathrm{kg}$ in shrimp and mussel tissues [31]. Along with the accumulation of iodine, marine invertebrates and algae can synthesize non-volatile iodinated organic molecules with a diverse structure, including monoiodotyrosine, diiodotyrosine, iodinated alkaloids, iodinated diterpenoids of briarane type and others [29, 37, 74, 81].

ISSN 1996-4536 (print) • ISSN 2311-0783 (on-line) • Біологічні Студії / Studia Biologica • 2018 • Том 12/№2 • С. 117-134 
Among the marine fish species studied, particularly high concentrations of iodine were found in the muscles of members of the family Gadidae with maximum iodine concentrations in cod (Gadus morhua) and haddock (Melanogrammus aeglefinus), reaching 12.7 and $9.2 \mathrm{mg} / \mathrm{kg}$ wet weight, respectively. Significantly lower levels of iodine were found in members of the family Salmonidae, namely 6-34 and 20-100 $\mu \mathrm{g} / \mathrm{kg}$ wet weight in the muscles of atlantic salmon (Salmo salar) and rainbow trout (Oncorhynchus mykiss), respectively [31].

lodine is needed by humans and all vertebrate animals for the synthesis of thyroid hormones, which control embryonic development, postnatal growth and metabolic rate. A functioning thyroid gland consisting of non-encapsulated follicles capable of concentrating iodide first appears in representatives of Agnatha such as the lamprey (Petromyzontiformes) [26]. In mammalian species, the thyroid gland is an encapsulated endocrine organ that is highly specialized in concentrating iodide from blood plasma and maintains the amount of this element at the levels required for the processes of hormonogenesis. In amphibians and teleost fishes, thyroid hormones are involved in the control of metamorphosis [57].

\section{2. lodine in human organism}

lodine is found in minimal quantities in the human body (from 15 to $20 \mathrm{mg}$ ), but is required for normal functioning of the thyroid gland, the production of thyroid hormones thyroxine $\left(T_{4}\right)$ and triiodothyronine $\left(T_{3}\right)$ and regulation of metabolism $[11,12,16,27,35$, 92]. Since the main part of iodine (more than $90 \%$ ) enters the human organism via the gastrointestinal tract, then adequate iodine nutrition is critical for maintaining the thyroid function and process of hormonogenesis. Inadequate iodine intake by humans leads to serious health problems due to thyroid dysfunction and insufficient formation of thyroid hormones. In cases of severe iodine deficiency, the endemic goitre, brain damage and other neurological abnormalities, physical development disorders and cognitive impairment can occur $[35,93,94]$. It has been proven that iodine deficiency is a common cause of mental disability, which can be avoided by appropriate supply of the body with iodine [35, 93].

lodine is bioavailable to mammals in the form of an iodide anion, which is readily absorbed from the small intestine, mostly from the duodenum [35]. The process is mediated mainly by sodium iodide symporter ( $\mathrm{Na}^{+} / \mathrm{I}^{-}$symporter, NIS) located in the cells of small intestinal epithelium [60]. NIS also provides uptake of iodide in the thyroid gland and over a wide range of non-thyroidal tissues [63]. The thyroid gland stores $70-80 \%$ of the total amount of iodine in the human body [35]. Part of the iodide is accumulated by extra-thyroidal tissues, such as the gastric mucosa, salivary glands and lactating mammary gland, which form the major extra-thyroidal iodide pool $[6,63,66]$.

lodide enters the thyroid follicular epithelial cells (thyrocytes) via two routes: 1) active transport involving membrane $\mathrm{Na}^{+} / \mathrm{I}^{-}$symporter (NIS), which is considered the main pathway of iodide entry; 2) diffusion through ion channels [56]. The $\mathrm{Na}^{+} / \mathrm{I}^{-}$symporter (also known as SLC5A5) is located at the basolateral plasma membrane of thyrocytes and mediates the process of active iodide transport using an electrochemical sodium gradient generated by $\mathrm{Na}^{+} / \mathrm{K}^{+}$-ATPase $[63,66]$. Owing to this transport system, the thyroid gland is capable of concentrating iodide 20-40 times with respect to blood plasma. The main stages of iodine metabolism in the thyroid gland are associated with the oxidation and organification of iodide at the cell-colloidal interface and in the follicular lu- 
men, followed by the formation and release of thyroid hormones. These processes require the presence of high molecular weight protein thyroglobulin (TG), membranebound enzyme thyroperoxidase (TPO), and dual oxidases DUOX1 and DUOX2, calcium-dependent NADPH-oxidases that supply $\mathrm{H}_{2} \mathrm{O}_{2}$ necessary for TPO activity $[23,83]$. Both oxidation and organification of iodide, that is, its incorporation into tyrosine residues in thyroglobulin, as well as a subsequent coupling reaction in which two tyrosine residues within TG molecules couple to form iodothyronines (either $T_{4}$ or $T_{3}$ ) are catalyzed by TPO. lodothyronines, bound with TG molecules, are stored in the colloid until thyroglobulin is taken up by follicular cells. To release thyroid hormones, the molecules of iodinated TG are internalized into the thyrocytes by micro- and macropinocytosis followed by proteolysis in lysosomes involving endopeptidases and exopeptidases. This process is accompanied by the release of $T_{4}$ and $T_{3}$, which are then secreted into the bloodstream from the basolateral surfaces of follicular cells [44]. The monocarboxylate channel (MCT8/SLC16A2) was shown to be involved in the efflux of thyroid hormones at the basolateral membrane.

lodide turnover in the thyroid also includes the formation of certain iodolipids (such as iodolactones and iodoaldehydes) that plays a role in the conditions of excess iodide, as well as iodothyronine deiodination. Within the thyroid gland, part of the thyroxine undergoes a deiodination process mediated by iodothyronine deiodinases (DIOs), selenoenzymes that are expressed in many types of cells, including thyrocytes [8, 10, 19, 78]. Thyroxine deiodination leads to the formation of $T_{3}$ (the active form of the thyroid hormone) or reverse triiodothyronine (3,3',5'-triiodothyronine, $\left.\mathrm{rT}_{3}\right)$, which is an inactive $\mathrm{T}_{3}$ isomer. Deiodination of monoiodotyrosine (MIT) and diiodotyrosine (DIT) formed in thyrocytes is catalysed by intracellular iodotyrosine-dehalogenase (DEHAL1) [83]. Process of hormonogenesis, as well as iodide uptake in thyrocytes, is regulated mainly by thyroid-stimulating hormone (TSH, thyrotropin) produced by the cells of anterior pituitary gland. Thyrotropin stimulates the expression of the genes of NIS, TG, TPO and TSH-receptor (TSHR) [23]. The TSH itself is under the control of thyrotropin-releasing hormone $(\mathrm{TRH})$ secreted from the hypothalamus.

lodine is released from the thyroid gland mainly in the form of thyroxine, and only a small amount of this element is excreted into the blood in the form of $\mathrm{T}_{3}$ (in humans, these values are $80-100 \mu \mathrm{g}$ and $3 \mu \mathrm{g}$ per day, respectively) [35]. Most of the $\mathrm{T}_{3}$ in the body is produced from $\mathrm{T}_{4}$ in extra-thyroidal tissues involving iodothyronine deiodinases DIO1 and DIO2, which catalyse the deiodination of the outer ring of thyroxine in the 5'-position [8, 10, 19, 49, 77, 78]. In peripheral tissues, both $\mathrm{T}_{4}$ and $\mathrm{T}_{3}$ can also be converted to inactive forms via deiodination of the inner ring by either type 3 deiodinase (DIO3) or DIO1. lodothyronine deiodinases have also been found in bone marrow cells and in blood leukocytes [8, 15].

It is generally accepted that thyroid hormones mediate the most important function of iodine in mammalian organism. Thyroid hormones $T_{4}$ and $T_{3}$ are potent bioregulators that act at different structural levels of human organism: they stimulate the synthesis and catabolism of biomolecules, maintain the level of the basic metabolism, and regulate proliferation, differentiation and apoptosis of cells [14, 16, 17, 84, 92]. Thyroid hormones are also involved in tissue regeneration, maturation and functional activity of organs and organ systems [7, 9, 27, 93], and oxygen-transport function of the blood [76, 80]. Being an integral part of thyroid hormones, iodine is necessary for normal activity of the central nervous system, cardiovascular system, musculoskeletal system, as well as for the re-

ISSN 1996-4536 (print) • ISSN 2311-0783 (on-line) • Біологічні Студії / Studia Biologica • 2018 • Том 12/№2 • C. 117-134 
productive, digestive, hematopoietic and immune systems [12, $27,28,64,84]$. lodine has some functions in the human body that are not mediated by its participation in the synthesis of thyroid hormones. In particular, reducing properties of iodide make it an important scavenger of reactive oxygen species [87]. At the same time, the oxidation of $\mathrm{I}^{-}$to hypo-iodite $\left(\mathrm{IO}^{-}\right)$makes it a potent oxidant with strong bactericidal activity. lodine can also act as anti-inflammatory, antiproliferative and cytotoxic agent and has a protective effect against several types of cancer [28, 87].

The above data show that iodine exhibits a wide range of effects in the human body, as well as in organisms that live in natural ecosystems. Various groups of biota, in turn, influence the iodine behaviour in the environmental compartments and contribute to iodine cycling in the global environment.

\section{CONCLUSIONS}

lodine is a trace element of the earth's crust, unevenly distributed between environmental compartments. The element is abundant in marine environment, sediments and subterranean brines, but it is scarce in terrestrial rocks, soils and continental waters. lodine is ubiquitous in the biosphere and serves as an important micronutrient for humans and vertebrate animals, which accumulate it primarily in the follicles of the thyroid gland. Being an indispensable component of thyroid hormones, iodine participates in the regulation of cellular metabolism and a host of vital functions in vertebrates. In human and animal organisms, iodine is necessary for normal activity of the central nervous system, cardiovascular system and other organ systems. Among plant organisms, brown algae are potent bioconcentrators of iodine from seawater, with the largest iodine amount reported in species of the Laminaria genus. Marine algae and phytoplankton together with microbial populations of soils and ocean waters, as well as terrestrial vegetation, mediate the processes of iodine biotransformation in natural environments and its volatilization to the atmosphere and, consequently, contribute significantly to the global iodine cycle.

1. Abdel-Moati M.A.R. lodine speciation in the Nile river estuary. Marine Chemistry, 1999; 65 : 211-225.

[DOI: https://doi.org/10.1016/S0304-4203(99)00003-1]

2. Aiuppa A., Baker D.R., Webster J.D. Halogens in volcanic systems. Chemical Geology, 2009; 263: 1-18.

[DOI: https://doi.org/10.1016/j.chemgeo.2008.10.005]

3. Alvarez F., Reich M., Perez-Fodich A., Snyder G., Muramatsu Y., Vargas G., Fehn U. Sources, sinks and long-term cycling of iodine in the hyperarid Atacama continental margin. Geochimica et Cosmochimica Acta, 2015; 161(15): 50-70.

[DOI: https://doi.org/10.1016/j.gca.2015.03.032]

4. Amachi S. Microbial contribution to global iodine cycling: volatilization, accumulation, reduction, oxidation, and sorption of iodine. Microbes and Environments, 2008; 23(4): 269-276. [Google Scholar]

5. Amachi S., Mishima Y., Shinoyama H., Muramatsu Y., Fujii T. Active transport and accumulation of iodide by newly isolated marine bacteria. Applied and Environmental Microbiology, 2005; 71: 741-745.

[DOI: https://doi.org/10.1128/AEM.71.2.741-745.2005]

6. Angelousi A., Nonni A., Kassi E., Kontzoglou K. Expression of sodium iodide symporter in human breast tissues. Journal of BUON, 2016; 21(1): 53-60.

[Google Scholar]

ISSN 1996-4536 (print) • ISSN 2311-0783 (on-line) • Біологічні Студії / Studia Biologica • 2018 • Том 12/№2 • С. 117-134 
7. Antoniak G.L. The effect of thyroxine and insulin on the hemopoiesis in animals during neonatal development. Tsitologiia, 1999; 41(6): 512-515. (In Russian). [PMID: 10505334]

8. Antoniak H.L., Babych N.O., Solohub L.I., Snityns'kyı̌ V.V. Role of iodothyronine-deiodinase in thyroid hormone mechanisms in animal and human cells. Ukr. Biokhim. Zh, 2002; 74(1): 5-18. (In Ukrainian). [PMID: 12199100]

9. Antoniak G.L., Ignatenko Iu.V., Babich N.O., Snitinskii V.V. Structure and function of thyroid hormone receptors. Tsitol. Genet, 2000; 34(5): 67-80. (In Ukrainian). [PMID: 11213634]

10. Antonyak H.L., Babych N.O., Solohub L.I. Structure and functions of iodothyronine deiodinases in human and animal cells. Uspekhi Sovremennoĭ Biologii, 2002; 122(3): 290-299. (In Russian). [Google Scholar]

11. Antonyak H., Pershyn O., Panas N., Lupak O., Hoivanovych N., Savytska O., Zhylishchych Y. lodine in the diet and human health. In: Ecology and human health (Krynski A., Tebug G.K., Voloshanska S., eds). Czestochowa: Educator, 2018. P. 35-52. [DOI: https://dx.doi.org/10.23856/W1706]

12. Antonyak H.L., Vlizlo V.V. Biochemical and geochemical role of iodine. Lviv, 2013. 390 p. (In Ukrainian). [Google Scholar]

13. Ashworth D.J., Shaw G., Butler A.P., Ciciani L. Soil transport and plant uptake of radio-iodine from near-surface groundwater. Journal of Environmental Radioactivity, 2003; 70: 99-114. [DOI: https://doi.org/10.1016/S0265-931X(03)00121-8]

14. Babich N.O., Antoniak G.L., Tymochko M.F. Effect of thyroxine on the activity of some enzymes of energy metabolism in bone marrow myeloid cells and blood neutrophils from piglets. Vopr. Med. Khim, 2000; 46(2): 162-167. (In Russian). [PMID: 10885037]

15. Babych N., Antonyak H., Sklyarov A. Developmental switches in the functioning of iodothyronine-5'-deiodinase in haemopoietic tissue. FASEB J, 1999; 13(5): 784.4. [Google Scholar]

16. Babych N., Antonyak H., Sklyarov A.Ya. The influence of thyroxine on intensity of energy metabolism in bone marrow myeloid cells and neutrophilic polymorphonuclear leukocytes of neonatal pig. Endocrine Regulations, 2000; 34(2): 73-81. [Google Scholar]

17. Babych N.O., Antoniak H.L., Tymochko M.F., Snityns'kyı̆ V.V. The effect of thyroxine on the enzymatic activity of the energy metabolism and antioxidant system in the neutrophilic granulocytes of piglets. Fiziol Zh, 2000; 46(3): 84-91. (In Ukrainian).

[PMID: 11059392]

18. Bell N., Hsu L., Jacob D.J., Blake D.R., Butler J.H., King D.B., Lobert J.M., Maier-Reimer E. Methyl iodide: Atmospheric budget and use as a tracer of marine convection in global models. Journal of Geophysical Research, 2002; 107(D17): 4340.

[DOI: https://doi.org/10.1029/2001JD001151]

19. Bianco A.C., Salvatore D., Gereben B., Berry M.J., Larsen P.R. Biochemistry, cellular and molecular biology, and physiological roles of the iodothyronine selenodeiodinases. Endocrine Reviews, 2002; 23(1): 38-89.

[DOI: https://doi.org/10.1210/edrv.23.1.0455]

20. Borst Pauwels G.W.F.H. lodine as a micronutrient for plants. Plant and Soil, 1961; 14: 665-671. [DOI: https://doi.org/10.1007/BF01666295]

21. Bouga M., Combet E. Emergence of seaweed and seaweed-containing foods in the UK: focus on labeling, iodine content, toxicity and nutrition. Foods, 2015; 4: 240-253.

[DOI: https://doi.org/10.3390/foods4020240]

ISSN 1996-4536 (print) • ISSN 2311-0783 (on-line) • Біологічні Студії / Studia Biologica • 2018 • Том 12/№2 • C. 117-134 
22. Burkholder J.B., Curtius J., Ravishankara A.R., Lovejoy E.R. Laboratory studies of the homogeneous nucleation of iodine oxides. Atmospheric Chemistry and Physics, 2004; 4: 19-34. [DOI: https://doi.org/10.5194/acp-4-19-2004]

23. Carvalho D.P., Dupuy C. Thyroid hormone biosynthesis and release. Molecular and Cellular Endocrinology, 2017; 458: 6-15.

[DOI: https://doi.org/10.1016/j.mce.2017.01.038]

24. Chance R., Baker A.R., Carpenter L., Jickells T.D. The distribution of iodide at the sea surface. Environmental Science: Processes \& Impacts, 2014; 16: 1841-1859.

[DOI: https://doi.org/10.1039/C4EM00139G]

25. Chance R., Baker A.R., Küpper F.C., Hughes C., Kloareg B., Malin B. Release and transformations of inorganic iodine by marine macroalgae. Estuarine, Coastal and Shelf Science, 2009; 82(3): 406-414.

[DOI: https://doi.org/10.1016/j.ecss.2009.02.004]

26. De Felice M., Di Lauro R. Thyroid development and its disorders: genetics and molecular mechanisms. Endocrine Reviews, 2004; 25(5): 722-746.

[DOI: https://doi.org/10.1210/er.2003-0028]

27. DeGroot L.J., Larsen P., Hennemann G. Thyroid hormone transport, cellular uptake, metabolism, and molecular action. In: The Thyroid and Its Diseases, 6th ed. Churchill Livingstone, N.Y., 1996: 61-111.

[Google Scholar]

28. De la Vieja A., Santisteban P. Role of iodide metabolism in physiology and cancer. Endocrine-Related Cancer, 2018; 25(4): R225-R245.

[DOI: http://doi.org/10.1530/ERC-17-0515]

29. Dembitsky V. Biogenic iodine and iodine-containing metabolites. Natural Product Communications, 2006; 1(2): 139-175.

[Google Scholar]

30. Eales J.G. lodine metabolism and thyroid-related functions in organisms lacking thyroid follicles: are thyroid hormones also vitamins? Proceedings of the Society for Experimental Biology and Medicine, 1997; 214(4): 302-317.

[DOI: https://doi.org/10.3181/00379727-214-44098]

31. European Food Safety Authority (EFSA). Opinion of the Scientific Panel on additives and products or substances used in animal feed (FEEDAP) on the use of iodine in feedingstuffs. The EFSA Journal, 2005; 168: 1-42.

[DOI: https://doi.org/10.2903/j.efsa.2005.168]

32. Fuge R., Johnson C.C. lodine and human health, the role of environmental geochemistry and diet, a review. Applied Geochemistry, 2015; 63: 282-302.

[DOI: https://doi.org/10.1016/j.apgeochem.2015.09.013]

33. Gilfedder B.S., Petri M., Biester H. lodine speciation and cycling in fresh waters: A case study from a humic rich headwater lake (Mummelsee). Journal of Limnology, 2009; 68(2): 396-408. [DOI: https://doi.org/10.3274/JL09-68-2-22]

34. Gonzali S., Kiferle C., Perata P. Iodine biofortification of crops: agronomic biofortification, metabolic engineering and iodine bioavailability. Current Opinion in Biotechnology, 2017, 44: 16-26.

[DOI: https://doi.org/10.1016/j.copbio.2016.10.004]

35. Hetzel B.S., Maberly G.F. Iodine. In: Trace Elements in Human and Animal Nutrition, 5th edn. (Mertz W., ed). N.Y.: Acad. Press, 1986; 2: 139-208.

[DOI: https://doi.org/10.1016/B978-0-08-092469-4.50006-6]

36. Hou X., Hansen V., Aldahan A., Possnert G., Lind O.C., Lujaniene G. A review on speciation of iodine-129 in the environmental and biological samples. Analytica Chimica Acta, 2009; 632(2): 181-196.

[DOI: https://doi.org/10.1016/j.aca.2008.11.013]

ISSN 1996-4536 (print) • ISSN 2311-0783 (on-line) • Біологічні Студії / Studia Biologica • 2018 • Том 12/№2 • С. 117-134 
37. Hwang B.S., Lee K., Yang C., Jeong E.J., Rho J.-R. Characterization and anti-inflammatory effects of iodinated acetylenic acids isolated from the marine sponges Suberites mammilaris and Suberites japonicas. Journal of Natural Products, 2013; 76(12): 2355-2359. [DOI: https://doi.org/10.1021/np400793r]

38. Isupov V., Vladimirov A., Sodov A., Kolpakova M., Shvartsev S., Volkova N. Hydromineral resources of saline lakes of Mongolia and Russian Altai. Advanced Materials Research, 2015; 1085: 166-170.

[DOI: https://doi.org/10.4028/www.scientific.net/AMR.1085.166]

39. Iwamoto K., Shiraiwa Y. Characterization of intracellular iodine accumulation by iodine-tolerant microalgae. Procedia Environmental Sciences, 2012; 15: 34-42.

[DOI: https://doi.org/10.1016/j.proenv.2012.05.007]

40. Kendrick M.A. Halogens. In: Encyclopedia of Geochemistry (White W.M., ed). Springer Internat. Publ. AG, 2016: 1-5.

[DOI: https://doi.org/10.1007/978-3-319-39193-9_95-1]

41. Keppler F., Borchers R., Elsner P., Fahimi I, Pracht J, Schöler HF. Formation of volatile iodinated alkanes in soil: results from laboratory studies. Chemosphere, 2003; 52(2): 477-483. [DOI: https://doi.org/10.1016/S0045-6535(03)00198-X]

42. Kesler S.E., Simon A.C. Mineral Resources, Economics and the Environment. Cambridge University Press, 2015. 446 p.

[Google Scholar]

43. Kodama S., Takahashi Y., Okumura K., Uruga T. Speciation of iodine in solid environmental samples by iodine K-edge XANES: application to soils and ferromanganese oxides. Science of The Total Environment, 2006; 363(1-3): 275-284.

[DOI: https://doi.org/10.1016/j.scitotenv.2006.01.004]

44. Kopp P., Cooper D.S. Thyroid hormone synthesis: thyroid iodine metabolism. In: Werner and Ingbar's the thyroid: a fundamental and clinical text, $10^{\text {th }}$ edn. (Braverman L.E., Cooper D.S., eds). Philadelphia: Lippincott, Williams \& Wilkins, 2013. P. 48-74.

[Google Scholar]

45. Küpper F.C., Carpenter L.J., McFiggans G.B., Palmer C.J., Waite T.J., Boneberg E.-M., Woitsch S., Weiller M., Abela R., Grolimund D., Potin P., Butler A., Luther III G.W., Kroneck P.M.H., Meyer-Klaucke W., Feiters M.C. lodide accumulation provides kelp with an inorganic antioxidant impacting atmospheric chemistry. Proceedings of the National Academy of Sciences USA, 2008; 105: 6954-6958.

[DOI: https://doi.org/10.1073/pnas.0709959105]

46. Küpper F.C., Kroneck P.M.H. lodine bioinorganic chemistry: physiology, structures, and mechanisms. In: lodine Chemistry and Applications (Kaiho T., ed). John Wiley \& Sons, Inc., 2015. P. 537-589.

[DOI: https://doi.org/10.1002/9781118909911.ch32]

47. Küpper F.C., Schweigert N., Argall E., Legendre JM, Vilter H, Kloareg B. lodine uptake in Laminariales involves extracellular, haloperoxidase-mediated oxidation of iodide. Planta, 1998; 207(2): 163-171.

[DOI: https://www.jstor.org/stable/23385468]

48. La Barre S., Potin P., Leblanc C., Delage L. The halogenated metabolism of brown algae (Phaeophyta), its biological importance and its environmental significance. Marine Drugs, 2010; 8(4): 988-1010.

[DOI: https://doi.org/10.3390/md8040988]

49. Larsen P.R., Zavacki A.M. Role of the iodothyronine deiodinases in the physiology and pathophysiology of thyroid hormone action. European Thyroid Journal, 2013; 1(4): 232-242. [DOI: https://doi.org/10.1159/000343922]

50. Leblanc C., Colin C., Cosse A., Delage L., La Barre S., Morin P., Fiévet B., Voiseux C., Ambroise Y., Verhaeghe E., Amouroux D., Donard O., Tessier E., Potin P. lodine transfers in the coastal marine environment: the key role of brown algae and of their vanadium-dependent haloperoxidases. Biochemie, 2006; 88: 1773-1785.

[DOI: https://doi.org/10.1016/j.biochi.2006.09.001]

ISSN 1996-4536 (print) • ISSN 2311-0783 (on-line) • Біологічні Студії / Studia Biologica • 2018 • Том 12/№2 • C. 117-134 
51. Leyva R., Sánchez-Rodríguez E., Ríos J.J., Rubio-Wilhelmi M.M., Romero L., Ruiz J.M., Blasco $B$. Beneficial effects of exogenous iodine in lettuce plants subjected to salinity stress. Plant Science, 2011; 181(2): 195-202.

[DOI: https://doi.org/10.1016/j.plantsci.2011.05.007]

52. Li H.P., Brinkmeyer R., Jones W.L., Zhang S., Xu C., Schwehr K.A., Santschi P.H., Kaplan D.I., Yeager C.M. lodide accumulation by aerobic bacteria isolated from subsurface sediments of a ${ }^{129} \mathrm{I}$-contaminated aquifer at the Savannah River Site, South Carolina. Applied and Environmental Microbiology, 2011; 77: 2153-2160.

[DOI: https://doi.org/10.1128/AEM.02164-10]

53. Lupak O.M., Kovalchuk H.Ya., Antonyak H.L. Potentiometric determination of the antioxidant activity of plant extracts of Calendula officinalis L. under the action of growth bio-stimulants. ScienceRise: Biological Science, 2017; 6(9): 10-13. (In Ukrainian). [DOI: https://doi.org/10.15587/2519-8025.2017.119086]

54. Lupak O., Kovalchuk H., Antonyak H. Comparative analysis of integrated antioxidant activity of inflorescences of Calendula officinalis L. plants grown in the conditions of Precarpathian area and the effect of growth biostimulants. Biological Resources and Nature Management $=$ Bioresursy i pryrodokorystuvannya, 2018; 10(1-2): 58-63. (In Ukrainian). [Google Scholar]

55. Marinova S., Yurukova L., Frontasyeva M.V., Steinnes E., Strelkova L. P., Marinov A., Karadzhinova A. G. Air pollution studies in Bulgaria using the moss biomonitoring technique. Ecological Chemistry and Engineering S, 2010; S17(1): 37-52. [Google Scholar]

56. McLanahan E.D., Andersen M., Fisher J. A biologically based dose-response model for dietary iodide and the hypothalamic-pituitary-thyroid axis in the adult rat: evaluation of iodide deficiency. Toxicological Sciences, 2008; 102(2): 241-253.

[DOI: https://doi.org/10.1093/toxsci/kfm312]

57. McMenamin S.K., Parichy D.M. Metamorphosis in teleosts. Current Topics in Developmental Biology, 2013; 103: 127-165.

[DOI: https://doi.org/10.1016/B978-0-12-385979-2.00005-8]

58. Moran J.E. Sources of iodine and iodine 129 in rivers. Water Resources Research, 2002; 38(8): 1149.

[DOI: https://doi.org/10.1029/2001WR000622]

59. Nath T., Raha P., Rakshit A. Sorption and desorption behaviour of iodine in alluvial soils of Varanasi, India. Agricultura, 2010; 7: 9-14.

[Google Scholar]

60. Nicola J.P., Carrasco N., Masini-Repiso A.M. Dietary I(-) absorption: expression and regulation of the $\mathrm{Na}(+) / /(-)$ symporter in the intestine. Vitamins \& Hormones, 2015; 98: 1-31.

[DOI: https://doi.org/10.1016/bs.vh.2014.12.002]

61. O'Neill H.St.C., Palme H. Composition of the silicate Earth: implications for accretion and core formation. In: The Earth's Mantle: Structure, Composition and Evolution - the Ringwood Volume (Jackson I., ed). Cambridge Univ. Press, 1998. P. 3-126. [Google Scholar]

62. Pearce E.N. National trends in iodine nutrition: Is everyone getting enough? Thyroid, 2007; 17: 823-827.

[DOI: https://doi.org/10.1089/thy.2007.0102]

63. Portulano C., Paroder-Belenitsky M., Carrasco N. The $\mathrm{Na}^{+} / I^{-}$symporter (NIS): Mechanism and medical impact. Endocrine Reviews, 2014; 35: 106-149.

[DOI: https://doi.org/10.1210/er.2012-1036]

64. Préau L., Fini J.B., Morvan-Dubois G., Demeneix B. Thyroid hormone signaling during early neurogenesis and its significance as a vulnerable window for endocrine disruption. Biochimica et Biophysica Acta, 2015; 1849(2): 112-121.

[DOI: https://doi.org/10.1016/j.bbagrm.2014.06.015]

ISSN 1996-4536 (print) • ISSN 2311-0783 (on-line) • Біологічні Студії / Studia Biologica • 2018 • Том 12/№2 • С. 117-134 
65. Prouty N.G., Roark E.B., Mohon L.M., Chang C.-C. Uptake and distribution of organo-iodine in deep-sea corals. Journal of Environmental Radioactivity, 2018; 187: 122-132. [DOI: https://doi.org/10.1016/j.jenvrad.2018.01.003]

66. Ravera S., Reyna-Neyra A., Ferrandino G., Amzel L. M., Carrasco N. The sodium/iodide symporter (NIS): molecular physiology and preclinical and clinical applications. Annual Review of Physiology, 2017; 79(1): 261-289.

[DOI: https://doi.org/10.1146/annurev-physiol-022516-034125]

67. Redeker K.R., Treseder K., Allen M. Ectomycorrhizal fungi: a new source of atmospheric methyl halides? Global Change Biology, 2004; 10(6): 1009-1016.

[DOI: https://doi.org/10.1111/j.1529-8817.2003.00782.x]

68. Risher J.F., Keith L.S. lodine and Inorganic lodides: Human Health Aspects. Geneva: WHO Press, 2009. $61 \mathrm{p}$.

[Google Scholar]

69. Robertson D.E., Cataldo D.A., Napier B.A., Krupka K.M., Sasser L.B. Literature review and assessment of plant and animal transfer factors used in performance assessment modeling. Division of Systems Analysis and Regulatory Effectiveness Office of Nuclear Regulatory Research U.S. Nuclear Regulatory Commission Washington, DC 20555-0001. 2003. 182 p. [Google Scholar]

70. Saini H.S., Attieh J.M., Hanson A.D. Biosynthesis of halomethanes and methanethiol by higher plants via a novel methyltransferase reaction. Plant, Cell \& Environment, 1995; 18(9): 1027-1033.

[DOI: https://doi.org/10.1111/j.1365-3040.1995.tb00613.x]

71. Saiz-Lopez A., Fernandez R. P., Ordóñez C., Kinnison D.E., Gómez Martín J.C., Lamarque J.-F., Tilmes $S$. lodine chemistry in the troposphere and its effect on ozone. Atmospheric Chemistry and Physics, 2014; 14: 13119-13143.

[DOI: https://doi.org/10.5194/acp-14-13119-2014]

72. Šeda M., Konečný R., Fiala K., Hladký J., Švehla J., Trávníček J. lodine content in running surface waters in areas with more intensive landscape management in the Czech Republic. Journal of Elementology, 2017; 22(1): 295-304.

[DOI: https://doi.org/10.5601/jelem.2015.20.4.1044]

73. Seki M., Oikawa J., Taguchi T. et al. Laccase-catalyzed oxidation of iodide and formation of organically bound iodine in soils. Environmental Science \& Technology, 2013; 47(1): 390-397. [DOI: https://doi.org/10.1021/es303228n]

74. Shen S., Liu D., Wei C., Proksch P., Lin W. Purpuroines A-J, halogenated alkaloids from the sponge lotrochota purpurea with antibiotic activity and regulation of tyrosine kinases. Bioorganic \& Medicinal Chemistry, 2012; 20: 6924-6928.

[DOI: https://doi.org/10.1016/j.bmc.2012.10.014]

75. Shetaya W.H., Young S.D., Watts M.J., Ander E.L., Bailey E.H. lodine dynamics in soils. Geochimica et Cosmochimica Acta, 2012; 77: 457-473.

[DOI: https://doi.org/10.1016/j.gca.2011.10.034]

76. Snitynsky $V$., Antonyak $H$. The hormonal regulation of blood respiratory function in cattle during the neonatal period. Annales De Zootechnie, 1995; 44 (Suppl. 1): 281. [Google Scholar]

77. Snityns'kyı̆ V.V., Antoniak H.L. Biochemical role of selenium. Ukr. Biokhim. Zh, 1994; 66(5): 3-16.

[PMID: 7747342]

78. St. Germain D.L., Galton V.A., Hernandez A. Minireview: Defining the roles of the iodothyronine deiodinases: current concepts and challenges. Endocrinology, 2009; 150(3): 1097-1107. [DOI: https://doi.org/10.1210/en.2008-1588]

79. Su Y.D., Su J.H., Hwang T.L., Wen Z.H., Sheu J.H., Wu J.C., Sung P.J. Briarane diterpenoids isolated from Octocorals between 2014 and 2016. Marine Drugs, 2017; 15: 44. [DOI: https://doi.org/10.3390/md15020044]

ISSN 1996-4536 (print) • ISSN 2311-0783 (on-line) • Біологічні Студії / Studia Biologica • 2018 • Том 12/№2 • C. 117-134 
80. Sukhomlinov B.F., Antoniak G.L., Trikulenko A.V. Effect of thyroxine on the hemoglobin affinity to oxygen and 2,3-diphosphoglycerate level in rat erythrocytes. Ukrainskii Biokhimicheskii Zhurnal, 1986; 58(2): 84-86.

[PMID:3705208]

81. Sun J.-F., Huang H., Chai X.-Y., Yang X.-W., Meng L., Huang C.-G., Zhou X.-F., Yang B., Hu J., Chen $X$.-Q. Dichotellides A-E, five new iodine-containing briarane type diterpenoids from Dichotella gemmacea. Tetrahedron, 2011; 67(6): 1245-1250.

[DOI: https://doi.org/10.1016/j.tet.2010.11.087]

82. Tagami K., Uchida S. Concentrations of chlorine, bromine and iodine in Japanese rivers. Chemosphere, 2006; 65(11): 2358-2365.

[DOI: https://doi.org/10.1016/j.chemosphere.2006.04.077]

83. Targovnik H.M., Citterio C.E., Rivolta C.M. lodide handling disorders (NIS, TPO, TG, IYD).

Best Practice \& Research Clinical Endocrinology \& Metabolism, 2017; 31(2): 195-212. [DOI: DOI: https://doi.org/10.1016/j.beem.2017.03.006]

84. Thompson C.K., Cline H.T. Thyroid hormone acts locally to increase neurogenesis, neuronal differentiation, and dendritic arbor elaboration in the tadpole visual system. Journal of Neuroscience, 2016; 36(40): 10356-10375.

[DOI: https://doi.org/10.1523/JNEUROSCI.4147-15.2016]

85. Thorenz U.R., Carpenter L.J., Huang R.-J. et al. Emission of iodine containing volatiles by selected microalgae species. Atmospheric Chemistry and Physics, 2014; 14: 13327-13335. [DOI: https://doi.org/10.5194/acp-14-13327-2014]

86. Turoski V. Chlorine and Chlorine Compounds in the Paper Industry. CRC Press, 1997. $400 \mathrm{p}$.

[Google Scholar]

87. Venturi S., Venturi M. lodide, thyroid and stomach carcinogenesis: Evolutionary story of a primitive antioxidant? European Journal of Endocrinology, 1999; 140: 371-372. [DOI: https://doi.org/10.1530/eje.0.1400371]

88. Vogt $R$. lodine compounds in the atmosphere. In: Reactive Halogen Compounds in the Atmosphere (Fabian P., Singh O.N., eds). Berlin, Heidelberg: Springer, 1999. 113-127 p. [DOI: https://doi.org/10.1007/10628761_4]

89. Watts M.J., O'Reilly J., Marcelli A., Coleman A., Ander E.L., Ward N.I. A snapshot of environmental iodine and selenium in La Pampa and San Juan provinces of Argentina. Journal of Geochemical Exploration, 2010; 107(2): 87-93.

[DOI: https://doi.org/10.1016/j.gexplo.2009.11.002]

90. Weng H.X., Yan A.L., Hong C.L., Qin YC, Pan L., Xie L.L. Biogeochemical transfer and dynamics of iodine in a soil-plant system. Environmental Geochemistry and Health, 2009; 31(3): 401-411.

[DOI: https://doi.org/10.1007/s10653-008-9193-6]

91. Whitehead D.C. The distribution and transformations of iodine in the environment. Environment International, 1984; 10: 321-339.

[DOI: https://doi.org/10.1016/0160-4120(84)90139-9]

92. Yen P.M., Brent G.A. Genomic and nongenomic actions of thyroid hormones. In: Werner and Ingbar's the thyroid: a fundamental and clinical text, $10^{\text {th }}$ edn. (Braverman L.E., Cooper D.S., eds). Philadelphia: Lippincott, Williams \& Wilkins, 2013: 127-137. [Google Scholar]

93. Zimmermann M.B. The importance of adequate iodine during pregnancy and infancy. World Review of Nutrition and Dietetics, 2016; 115: 118-124.

[DOI: https://doi.org/10.1159/000442078]

94. Zimmermann M.B., Boelaert K. lodine deficiency and thyroid disorders. The Lancet Diabetes \& Endocrinology, 2015; 3(4): 286-295.

[DOI: https://doi.org/10.1016/S2213-8587(14)70225-6]

ISSN 1996-4536 (print) • ISSN 2311-0783 (on-line) • Біологічні Студії / Studia Biologica • 2018 • Том 12/№2 • С. 117-134 


\title{
ЙОД В АБІОТИЧНОМУ ТА БІОТИЧНОМУ СЕРЕДОВИЩАХ
}

\author{
Г. Л. Антоняк', Н. Є. Панас ${ }^{2}$, О. І. Першин ${ }^{3}$, О. І. Поліщук', Н. К. Гойванович4 \\ 1 Львівський національний університет імені Івана Франка \\ вул. Саксаганського, 1, Львів 79005, Україна \\ e-mail: halyna_antonyak@yahoo.com \\ 2 Львівський національний аграрний університет \\ вул. Володимира Великого, 1, Дубляни, Львівська обл. 80381, Україна \\ ${ }^{3}$ Львівський національний медичний університет імені Данила Галицького \\ вул. Пекарська, 69, Львів 9010, Україна \\ ${ }^{4}$ Дрогобицький державний педагогічний університет імені Івана Франка \\ вул. Т. Шевченка, 23, Дрогобич, Львівська обл. 82100, Україна
}

Йод, мікроелемент, що належить до галогенів, є природним компонентом навколишнього середовища. Проте розподіл йоду в різних компартментах природного середовища нерівномірний: його вміст невисокий у ґрунтотвірних гірських породах, ґрунтах і континентальних водах, але значно більший у морському середовищі та багатих на органічну речовину осадових породах. Йод широко розповсюджений у біосфрері та міститься практично в усіх організмах, і евкаріотах, і прокаріотах. У людини і хребетних тварин йод використовується насамперед у процесах синтезу гормонів щитоподібної залози, які беруть участь у регуляції клітинного метаболізму та життєво важливих функцій організму. У людини неадекватне споживання йоду може призводити до серйозних проблем зі здоров'ям через дисфункцію щитоподібної залози та недостатнє утворення тиреоїдних гормонів (ендемічний зоб, неврологічні аномалії, когнітивні розлади, порушення фрізичного розвитку та ін.). Багато інших груп біоти, які населяють різні екосистеми, здатні ефективно концентрувати йод з абіотичних середовищ і синтезувати різноманітні йодовмісні органічні сполуки. Деякі з цих сполук можуть виконувати метаболічні та сигнальні функції в організмах, які їх продукують, а інші, такі як леткі галогеновуглеводні, беруть участь у перенесенні йоду з морського та наземного середовища в атмосферу. Отже, наземні, ґрунтові та водяні організми (зокрема, мікроорганізми), які накопичують, метаболізують і випаровують йод, опосередковують процеси біотрансформації елемента у природному середовищі та сприяють його глобальному циклу. Морські організми (водорості, безхребетні) ефективніше концентрують йод порівняно з наземною біотою. Бурі водорості роду Laminaria - найпотужніші акумулятори йоду серед усіх живих систем. У цій статті проаналізовано розподіл йоду в абіотичному та біотичному середовищах і залучення біотичних процесів у біогеохімічний цикл цього елемента.

Ключові слова: йод, навколишнє середовище, екосистеми, біота, морські водорості, гормони щитоподібної залози

Одержано: 07.08.2018

ISSN 1996-4536 (print) • ISSN 2311-0783 (on-line) • Біологічні Студії / Studia Biologica • 2018 • Том 12/№2 • С. 117-134 